\title{
Hubungan Faktor Risiko Terhadap Kejadian Sindroma Koroner Akut pada Pasien Dewasa Muda di RSUP Dr. M. Djamil Padang
}

\author{
Anggita Tiara Pramadiaz ${ }^{1}$, Muhammad Fadil ${ }^{2}$, Henny Mulyani ${ }^{3}$
}

\begin{abstract}
Abstrak
Sumatera Barat merupakan provinsi dengan prevalensi penyakit jantung tertinggi ke-4 di Indonesia. Sindroma Koroner Akut (SKA) merupakan suatu spektrum perjalanan aterosklerosis pada Penyakit Jantung Koroner (PJK). Prevalensi penyakit ini meningkat diperkirakan karena faktor risiko seperti; jenis kelamin, riwayat keluarga, diabetes melitus, hipertensi, dislipidemia dan merokok. Tujuan penelitian ini adalah menentukan hubungan faktor risiko dengan kejadian SKA pada dewasa muda..Ini merupakan penelitian analitik observasional dengan desain potong lintang yang dilakukan di RSUP.M. Djamil Padang dari Juni 2014 sampai Oktober 2014. Populasi penelitian ini adalah seluruh pasien SKA berusia $\leq 45$ tahun yang dirawat dari 1 Januari 2011 - 31 Desember 2013 sebanyak 66 orang sebagai subjek penelitian. Data pasien didapatkan dari rekam medik. Data dideskripsikan dengan tabel dan dianalisis dengan uji chi-square dan regresi logistik. Distribusi frekuensi terbanyak pasien SKA terdapat pada laki-laki $(74,2 \%)$, riwayat merokok (63,6\%) dan hipertensi (37,9\%). Hasil uji chi-square menunjukan terdapat hubungan antara hipertensi dan riwayat keluarga dengan kejadian SKA pada dewasa muda.Pasien dewasa muda dengan hipertensi berisiko terkena SKA 0,301 kali lebih besar.Hipertensi merupakan faktor yang paling berpengaruh terhadap kejadian SKA pada pasien dewasa muda.
\end{abstract}

Kata kunci: sindroma koroner akut, penyakit jantung koroner, faktor risiko

\begin{abstract}
West Sumatra is the 4th highest province in prevalence of heart disease in Indonesia. Acute Coronary Syndromes (ACS) is a spectrum of atherosclerosis in Cardiac Heart Disease (CHD). The prevalence of this disease has increased related to risk factors, such as; gender, family history, diabetes mellitus, hypertension and smoking. The objective of this study was to determine the relationship of risk factors of ACS in young adults. This was an analytic observational cross-sectional design conducted at Dr.M. Djamil Padang Hospital from June 2014 - October 2014. The populations were ACS patients age $\leq 45$ years old which hodpitalized from January 1st 2011 - December 31 st 2013 to 66 samples as research subject. The data was retrieved from medical record. Data described in tables and analyzed with the chi-square test and logistic regression. The frequency distributions of most ACS patients are males (74,2\%), smoking history (63,6\%), and hypertension (37,9\%). Chi-square test result shows that hypertension and family history are related to ACS events in young adults. ACS events are more likely to occur 0,301 times in young adults with hypertension. Hypertension is the most influencing factor of ACS events in young adults.
\end{abstract}

Keywords: acute coronary syndromes, coronary heart disease, risk factors

Affiliasi penu)lis: 1. Pendidikan Dokter FK UNAND (Fakultas Kedokteran Universitas Andalas Padang, 2. Bagian Kardiologi dan kedokteran Vaskular FK UNAND, 3. Bagian Patologi Anatomi FK UNAND
Korespondensi: Anggita Tiara Pramadiaz,email :

anggitapramadiaz@yahoo.com, Telp: 085766521131 


\section{PENDAHULUAN}

Penyakit Jantung Koroner (PJK) adalah kondisi yang disebabkan oleh penurunan aliran darah pada miokardium yang diakibatkan proses aterosklerosis pada pembuluh darah koroner. ${ }^{1}$ PJK merupakan penyebab utama kematian yaitu satu dari enam kematian di Amerika Serikat pada tahun $2010 .^{2}$ Riset Kesehatan Dasar (RISKESDAS) tahun 2013 menyatakan prevalensi PJK di Indonesia berdasarkan diagnosis dokter atau gejala sebesar 1,5 persen. $^{3} \mathrm{Di}$ RS Pusat Jantung Nasional Harapan Kita, terjadi peningkatan jumlah kasus dari tahun 2000-2009. Dalam 10 tahun terakhir ini terdapat peningkatan operasi koroner sebesar 83\%. ${ }^{4}$ Kejadian PJK di Sumatera Barat menempati posisi ke-4 setelah Sulawesi Tengah, Aceh dan Jakarta. ${ }^{3}$

SKA dapat berupa angina pektoris tidak stabil (APTS), infark miokard akut dengan elevasi segmen ST (IMAEST), atau infark miokard akut non-elevasi segmen ST (IMANEST). Pasien dengan kriteria nyeri dada akut khas infark disertai adanya elevasi pada segmen ST yang persisten (>20 menit) dikelompokan dalam IMAEST. Sedangkan pasien dengan nyeri dada akut tetapi tanpa elevasi segmen ST yang persisten dikelompokan sebagai IMANEST atau APTS. Gambaran elektrokardiografi ini bisa terdapat depresi segmen ST yang persisten/transien atau inversi gelombang $\mathrm{T}$, gelombang $\mathrm{T}$ yang datar, gelombang $\mathrm{T}$ yang pseudo-normal atau tidak ada perubahan gelombang EKG. IMANEST didiagnosis jika terdapat peningkatan pada troponin, jika tidak maka akan didiagnosis sebagai APTS. ${ }^{5}$

Patofisiologi SKA melibatkan ateroskelerosis yang merupakan proses terbentuknya plak yang berdampak pada intima dari arteri. Proses aterosklerosis ini terjadi sepanjang usia sebelum akhirnya memberikan manifestasi klinis. Beberapa faktor risiko yang mempengaruhi proses ini adalah hiperkolesterolemia, hipertensi, diabetes, dan merokok. Faktor risiko ini merusak endotelium pembuluh darah dan akhirnya menyebabkan disfungsi endotel yang membantu proses aterosklerosis. ${ }^{6}$

Beberapa tahun terakhir ini PJK terlihat mengenai pasien dewasa muda. Hal ini membutuhkan perhatian karena bisa menyebabkan morbiditas dan mortalitas yang prematur. Pasien SKA pada dewasa muda banyak mengenai pria dibanding wanita. $^{7}$ Sebanyak $18 \%$ laki-laki dan $23 \%$ perempuan pada usia 40 tahun keatas bisa meninggal karena infark miokard. Diperkirakan sekitar sepertiga dari pasien IMAEST bisa meninggal dalam jangka waktu 24 jam setelah iskemia serta risiko mortilitas dan morbiditas lebih rendah pada pasien APTS/IMANEST. ${ }^{8}$

Tingginya risiko mortalitas yang dapat diakibatkan oleh SKA, serta komplikasi yang ditimbulkan, maka diperlukan penelitian lebih lanjut mengenai penyakit ini.

\section{METODE}

Jenis penelitian ini adalah analitik observasional dengan desain studi potong lintang melalui pengambilan data rekam medis pasien sindroma koroner akut di RSUP. M. Djamil Padang. Penelitian dilakukan dari Juni 2014 sampai Oktober 2014 dan data rekam medis yang diambil yaitu dimulai dari 1 Januari 2011 sampai 31 Desember 2013 di RSUP M. Djamil Padang, Sumatera Barat.

Populasi penelitian ini adalah pasien SKA yang berobat ke RSUP dr. M. Djamil Padang pada 1 Januari 2011 sampai 31 Desember 2013 berusia < 45 tahun. Sampel pada penelitian ini diambil dengan teknik total sampling yaitu seluruh populasi yang memenuhi kriteria inklusi dinyatakan sebagai sampel.

Analisis data pada penelitian ini menggunakan analisis univariat untuk melihat distribusi frekuensi, analisis bivariat menggunakan uji chi-square pada tingkat kepercayaan 95\%, bila $p<0,05$ menunjukkan adanya hubungan yang bermakna antara variabel independen dengan variabel dependen. Analisis multivariat untuk melihat kekuatan hubungan antara variabel dependen dan independen menggunakan analisis regresi logistik. Analisis multivariat dilakukan jika pada analisis bivariat ada variabel yang memiliki nilai $p<0,25$.

\section{HASIL}

\section{Analisis Univariat}

Selama periode 1 Januari 2011 - 31 Desember 2013 tercatat sebanyak 97 pasien SKA yang berusia $\leq$ 45 tahun, akan tetapi hanya sebanyak 66 pasien yang memenuhi kriteria penelitian. Kontrol pada penelitian 
ini diambil dari pasien SKA berusia $>45$ tahun yang berobat ke RSUP dr. M. Djamil Padang pada 1 Januari 2011 sampai 31 Desember 2013 yang diambil secara random sesuai jumlah sampel pertahun.

Distribusi jumlah pasien SKA berusia $\leq 45$ tahun di RSUP. M. Djamil selalu meningkat dari tahun 2011 sampai 2013. Pada tahun 2011 ditemukan sebanyak 14 pasien, tahun 2012 sebanyak 22 pasien, dan tahun 2013 sebanyak 30 pasien. Pasien yang didiagnosis APTS terdapat sebanyak 28 pasien, 28 pasien didiagnosis IMAEST dan 10 pasien didiagnosis IMANEST. Usia rata-rata pada subjek penelitian ini adalah 40 tahun.

Mayoritas subjek penelitian yaitu sebanyak 49 orang adalah laki-laki dan 17 orang perempuan. Kebanyakan pasien memiliki riwayat merokok yang positif yaitu sebanyak 42 orang, sementara itu hanya 8 pasien yang memiliki riwayat keluarga pernah menderita SKA atau PJK sebelumnya. Pada subjek penelitian ini terdapat 25 pasien yang sebelumnya telah atau didiagnosis hipertensi. Pasien yang sebelumnya telah atau didiagnosis diabetes mellitus pada saat masuk rumah sakit sebanyak 19 orang dan pasien yang sebelumnya telah atau didiagnosis dislipidemia pada saat masuk rumah sakit ada sebanyak 18 orang. Umumnya subjek penelitian memiliki faktor risiko lebih dari satu yaitu sebanyak 50 orang.

Pada kontrol terdapat peningkatan jumlah pasien perempuan yang terkena SKA yaitu sebanyak 22 orang dan sisanya laki-laki sebanyak 44 orang. Dari seluruh kontrol, tidak ada pasien yang memiliki riwayat keluarga yang positif. Pasien yang menderita hipertensi pada kontrol paling banyak yaitu sebanyak 43 orang. Ditemukan sebanyak 11 orang pasien yang menderita dislipidemia. Distribusi pasien yang memiliki riwayat merokok yang positif masih tinggi yaitu sebanyak 37 orang dan distribusi diabetes mellitus tidak jauh berbeda dengan subjek yaitu sebanyak 20 orang.Pasien yang memiliki faktor risiko lebih dari satu juga tidak jauh berbeda dengan subjek yaitu 51 orang.
Tabel 1. Distribusi frekuensi faktor risiko SKA pada dewasa muda

$$
\text { Sampel Kontrol }
$$

\begin{tabular}{|c|c|c|c|c|}
\hline \multicolumn{5}{|l|}{ Tahun } \\
\hline 2011 & 14 & $21,2 \%$ & 14 & $21,2 \%$ \\
\hline 2012 & 22 & $33,3 \%$ & 22 & $33,3 \%$ \\
\hline 2013 & 30 & $45,5 \%$ & 30 & $45,5 \%$ \\
\hline \multicolumn{2}{|l|}{ Jenis SKA } & $42,4 \%$ & 28 & $42,4 \%$ \\
\hline APTS & 28 & $42,4 \%$ & 26 & $39,4 \%$ \\
\hline IMAEST & 28 & $15,2 \%$ & 12 & $18,2 \%$ \\
\hline \multirow[t]{2}{*}{ IMANEST } & 10 & & & \\
\hline & & $74,2 \%$ & 44 & $66,7 \%$ \\
\hline Jenis & & $25,8 \%$ & 22 & $33,3 \%$ \\
\hline Kelamin & 49 & & & \\
\hline Laki-laki & 17 & & & \\
\hline \multicolumn{5}{|l|}{ Perempuan } \\
\hline Riwayat & & $12,2 \%$ & 0 & $0 \%$ \\
\hline Keluarga & & $87,8 \%$ & 6 & $100 \%$ \\
\hline Ada & 8 & & & \\
\hline Tidak & 58 & & & \\
\hline Diabetes & & $28,8 \%$ & 20 & $28,8 \%$ \\
\hline Melitus & & $71,2 \%$ & 46 & $71,2 \%$ \\
\hline $\mathrm{Ya}$ & 19 & & & \\
\hline \multirow[t]{2}{*}{ Tidak } & 47 & & & \\
\hline & & $37,9 \%$ & 43 & $37,9 \%$ \\
\hline Hipertensi & & $62,1 \%$ & 23 & $62,1 \%$ \\
\hline $\mathrm{Ya}$ & 25 & & & \\
\hline \multirow[t]{2}{*}{ Tidak } & 41 & & & \\
\hline & & $27,3 \%$ & 11 & $16,7 \%$ \\
\hline Dislipidemia & & $72,7 \%$ & 55 & $83,3 \%$ \\
\hline Ya & 18 & & & \\
\hline Tidak & 48 & & & \\
\hline Riwayat & & $63,6 \%$ & 37 & $56,1 \%$ \\
\hline Merokok & & $36,4 \%$ & 29 & $43,9 \%$ \\
\hline Perokok & 42 & & & \\
\hline Tidak & 24 & & & \\
\hline perokok & & $100 \%$ & 66 & $100 \%$ \\
\hline Jumlah & 66 & & & \\
\hline
\end{tabular}




\section{Analisis Bivariat}

Tabel 2. Hasil analisis hubungan jenis kelamin terhadap kejadian SKA pada Usia $\leq 45$ Tahun

\begin{tabular}{|c|c|c|c|c|}
\hline $\begin{array}{l}\text { Jenis } \\
\text { Kelamin }\end{array}$ & $\begin{array}{c}\text { SKA } \leq 45 \text { th } \\
\text { (Sampel) }\end{array}$ & $\begin{array}{c}\text { SKA >45 th } \\
\text { (Kontrol) }\end{array}$ & Total & $\mathbf{p}$ \\
\hline Laki-laki & $\begin{array}{c}49 \\
(74,2 \%)\end{array}$ & $\begin{array}{c}44 \\
(66,7 \%)\end{array}$ & $\begin{array}{c}93 \\
(70,5 \%)\end{array}$ & \\
\hline Perempuan & $\begin{array}{c}17 \\
(25,8 \%)\end{array}$ & $\begin{array}{c}22 \\
(33,3 \%)\end{array}$ & $\begin{array}{c}39 \\
(29,5 \%)\end{array}$ & 0,256 \\
\hline Total & $\begin{array}{c}66 \\
(100 \%)\end{array}$ & $\begin{array}{c}66 \\
(100 \%)\end{array}$ & $\begin{array}{c}132 \\
(100 \%)\end{array}$ & \\
\hline
\end{tabular}

Hasil uji chi-square, didapatkan nilai $p=0,256$. $\mathrm{Hal}$ ini berarti tidak terdapat hubungan yang signifikan antara jenis kelamin dengan kejadian SKA pada dewasa muda walaupun laki-laki merupakan faktor risiko terbanyak.

Tabel 3. Hasil analisis hubungan riwayat keluarga terhadap kejadian SKA pada usia $\leq 45$ tahun

\begin{tabular}{|c|c|c|c|c|}
\hline $\begin{array}{l}\text { Riwayat } \\
\text { Keluarga }\end{array}$ & $\begin{array}{c}\text { SKA } \leq 45 \text { th } \\
\text { (Sampel) }\end{array}$ & $\begin{array}{c}\text { SKA }>45 \text { th } \\
\text { (Kontrol) }\end{array}$ & Total & $\mathbf{p}$ \\
\hline Ada & $\begin{array}{c}8 \\
(12,2 \%)\end{array}$ & $\begin{array}{c}0 \\
(0 \%)\end{array}$ & $\begin{array}{c}8 \\
(6,1 \%)\end{array}$ & \\
\hline Tidak & $\begin{array}{c}58 \\
(87,8 \%)\end{array}$ & $\begin{array}{c}66 \\
(100 \%)\end{array}$ & $\begin{array}{c}124 \\
(93,9 \%)\end{array}$ & 0,006 \\
\hline Total & $\begin{array}{c}66 \\
(100 \%)\end{array}$ & $\begin{array}{c}66 \\
(100 \%)\end{array}$ & $\begin{array}{c}132 \\
(100 \%)\end{array}$ & \\
\hline
\end{tabular}

Uji Fisher Exact mendapatkan nilai $p=0,006$. Hal ini berarti terdapat hubungan yang signifikan antara riwayat keluarga dengan kejadian SKA pada dewasa muda.

Tabel 4. Hasil analisis hubungan diabetes melitus terhadap kejadian SKA pada usia $\leq 45$ tahun

\begin{tabular}{|c|c|c|c|c|}
\hline $\begin{array}{l}\text { Diabetes } \\
\text { melitus }\end{array}$ & $\begin{array}{c}\text { SKA } \leq 45 \text { th } \\
\text { (Sampel) }\end{array}$ & $\begin{array}{l}\text { SKA>45 th } \\
\text { (Kontrol) }\end{array}$ & Total & $\begin{array}{c}p \\
(<0,05)\end{array}$ \\
\hline Ya & $\begin{array}{c}19 \\
(28,8 \%)\end{array}$ & $\begin{array}{c}20 \\
(28,8 \%)\end{array}$ & $\begin{array}{c}39 \\
(29,5 \%)\end{array}$ & \\
\hline Tidak & $\begin{array}{c}47 \\
(71,2 \%)\end{array}$ & $\begin{array}{c}46 \\
(71,2 \%)\end{array}$ & $\begin{array}{c}93 \\
(70,5 \%)\end{array}$ & 0,849 \\
\hline Total & $\begin{array}{c}66 \\
(100 \%)\end{array}$ & $\begin{array}{c}66 \\
(100 \%)\end{array}$ & $\begin{array}{c}132 \\
(100 \%)\end{array}$ & \\
\hline
\end{tabular}

Hasil uji chi-square, didapatkan nilai $p=0,849$. Hal ini berarti tidak terdapat hubungan yang signifikan antara diabetes melitus dengan kejadian SKA pada dewasa muda.

Tabel 5. Hasil analisis hubungan hipertensi terhadap kejadian SKA pada usia $\leq 45$ tahun

\begin{tabular}{|c|c|c|c|c|}
\hline Hipertensi & $\begin{array}{r}\text { SKA } \leq 45 \text { th } \\
\text { (Sampel) }\end{array}$ & $\begin{array}{l}\text { SKA }>45 \text { th } \\
\text { (Kontrol) }\end{array}$ & Total & $\mathbf{p}$ \\
\hline $\mathrm{Ya}$ & $\begin{array}{c}25 \\
(37,9 \%)\end{array}$ & $\begin{array}{c}43 \\
(37,9 \%)\end{array}$ & $\begin{array}{c}68 \\
(51,5 \%)\end{array}$ & \\
\hline Tidak & $\begin{array}{c}41 \\
(62,1 \%)\end{array}$ & $\begin{array}{c}23 \\
(62,1 \%)\end{array}$ & $\begin{array}{c}64 \\
(48,5 \%)\end{array}$ & 0,002 \\
\hline Total & $\begin{array}{c}66 \\
(100 \%)\end{array}$ & $\begin{array}{c}66 \\
(100 \%)\end{array}$ & $\begin{array}{c}132 \\
(100 \%)\end{array}$ & \\
\hline
\end{tabular}

Uji chi-square, didapatkan nilai $p=0,002$. Hal ini berarti terdapat hubungan yang signifikan antara hipertensi dengan kejadian SKA pada dewasa muda.

Tabel 6. Hasil analisis hubungan dislipidemia terhadap kejadian SKA pada usia $\leq 45$ tahun

\begin{tabular}{|c|c|c|c|c|}
\hline Dislipidemia & $\begin{array}{c}\text { SKA } \leq 45 \text { th } \\
\text { (Sampel) }\end{array}$ & $\begin{array}{l}\text { SKA >45 th } \\
\text { (Kontrol) }\end{array}$ & Total & p \\
\hline Ya & $\begin{array}{c}18 \\
(27,3 \%)\end{array}$ & $\begin{array}{c}11 \\
(16,7 \%)\end{array}$ & $\begin{array}{c}29 \\
(22,0 \%)\end{array}$ & \\
\hline Tidak & $\begin{array}{c}48 \\
(72,7 \%)\end{array}$ & $\begin{array}{c}55 \\
(83,3 \%)\end{array}$ & $\begin{array}{c}103 \\
(78,0 \%)\end{array}$ & 0,141 \\
\hline Total & $\begin{array}{c}66 \\
(100 \%)\end{array}$ & $\begin{array}{c}66 \\
(100 \%)\end{array}$ & $\begin{array}{c}132 \\
(100 \%)\end{array}$ & \\
\hline
\end{tabular}

Hasil uji chi-square, didapatkan nilai $p=0,141$. Hal ini berarti tidak terdapat hubungan yang signifikan antara dislipidemia dengan kejadian SKA pada dewasa muda.

Tabel 7. Hasil analisis hubungan riwayat merokok terhadap kejadian SKA pada usia $\leq 45$ tahun

\begin{tabular}{|c|c|c|c|c|}
\hline $\begin{array}{l}\text { Riwayat } \\
\text { Merokok }\end{array}$ & $\begin{array}{l}\text { SKA } \leq 45 \text { th } \\
\text { (Sampel) }\end{array}$ & $\begin{array}{l}\text { SKA 45th } \\
\text { (Kontrol) }\end{array}$ & Total & p \\
\hline Perokok & $\begin{array}{c}42 \\
(63,6 \%)\end{array}$ & $\begin{array}{c}37 \\
(56,1 \%)\end{array}$ & $\begin{array}{c}79 \\
(59,8 \%)\end{array}$ & \\
\hline Tidak Perokok & $\begin{array}{c}24 \\
(36,4 \%)\end{array}$ & $\begin{array}{c}29 \\
(43,9 \%)\end{array}$ & $\begin{array}{c}53 \\
(40,2 \%)\end{array}$ & 0,288 \\
\hline Total & $\begin{array}{c}66 \\
(100 \%)\end{array}$ & $\begin{array}{c}66 \\
(100 \%)\end{array}$ & $\begin{array}{c}132 \\
(100 \%)\end{array}$ & \\
\hline
\end{tabular}


Hasil uji chi-square, didapatkan nilai $\mathrm{p}=0,288$. Hal ini berarti tidak terdapat hubungan yang signifikan antara riwayat merokok dengan kejadian SKA pada dewasa muda walaupun riwayat merokok merupakan faktor risiko kedua terbanyak.

\section{Analisis Multivariat}

Variabel yang akan dianalisis adalah variabel yang memiliki nilai $p<0,25$ pada analisis bivariat. Setelah dilakukan analisis pada enam variabel, terdapat tiga variabel yang memenuhi kriteria analisis multivariat, yaitu riwayat keluarga $(p=0,006)$, hipertensi ( $p=0,002)$, dan dislipidemia $(p=0,141)$. Tabel 8 menunjukan data awal variabel yang memenuhi kriteria inklusi analisis multivariat.

Variabel dikatakan bermakna apabila memenuhi $p<0,05$. Variabel yang memenuhi kriteria adalah hipertensi dengan nilai $p=0,001$ dengan nilai eksponen beta 0,301 . Maknanya pasien dewasa muda yang menderita hipertensi memiliki risiko 0,301 kali lebih besar untuk terkena SKA.Berdasarkan data diatas, dapat disimpulkan bahwa hipertensi merupakan variabel yang paling berpengaruh terhadap kejadian SKA pada pasien dewasa muda di RSUP.M. Djamil Padang periode 2011-2013.

Tabel 8. Model 1 analisis multivariat uji regresi logistik faktor risiko yang berpengaruh terhadap kejadian SKA pada usia $\leq 45$ tahun

\begin{tabular}{lcccc}
\hline Variabel & & $\begin{array}{c}\text { SKA } \leq \mathbf{4 5} \text { th } \\
\text { (Sampel) }\end{array}$ & $\begin{array}{c}\text { SKA }>\text { 45 th } \\
\text { (Kontrol) }\end{array}$ & $\mathbf{p}$ \\
\hline Riwayat & Ada & 8 & 0 & \\
Keluarga & Tidak & 58 & 66 & 0,999 \\
& & $(87,8 \%)$ & $(100 \%)$ & \\
\hline & Ya & 25 & 43 & 0,003 \\
Hipertensi & & $(37,9 \%)$ & $(37,9 \%)$ & \\
& Tidak & 41 & 23 & \\
& & $(62,1 \%)$ & $(62,1 \%)$ & \\
\hline & Ya & 18 & 11 & 0,061 \\
Dislipidemia & & $(27,3 \%)$ & $(16,7 \%)$ & \\
& Tidak & 48 & 103 & \\
& & $(72,7 \%)$ & $(78,0 \%)$ & \\
\hline
\end{tabular}

Pada Tabel 9 dapat dilihat ada eliminasi dari Tabel 8 dan menunjukan variabel-variabel yang paling dominan berdasarkan analisis statistik.
Tabel 9. Model 2 Analisis Multivariat Uji Regresi Logistik Faktor Risiko Yang Berpengaruh Terhadap Kejadian SKA pada Usia $\leq 45$ Tahun

\begin{tabular}{|c|c|c|c|c|c|}
\hline \multicolumn{2}{|l|}{ Variabel } & $\begin{array}{c}\text { SKA } \leq \\
45 \text { th } \\
\text { (Sampel) }\end{array}$ & $\begin{array}{c}\text { SKA > } \\
45 \text { th } \\
\text { (Kontrol) }\end{array}$ & p & $\begin{array}{l}\text { Exp } \\
\text { (B) }\end{array}$ \\
\hline \multirow{4}{*}{ Hipertensi } & $\mathrm{Ya}$ & 25 & 43 & \multirow{4}{*}{0,001} & \multirow{4}{*}{0,301} \\
\hline & & $(37,9 \%)$ & $(37,9 \%)$ & & \\
\hline & Tidak & 41 & 23 & & \\
\hline & & $(62,1 \%)$ & $(62,1 \%)$ & & \\
\hline \multirow{4}{*}{ Dislipidemia } & $\overline{Y a}$ & 18 & 11 & \multirow{4}{*}{0,079} & \multirow{4}{*}{2,222} \\
\hline & & $(27,3 \%)$ & $(16,7 \%)$ & & \\
\hline & Tidak & 48 & 103 & & \\
\hline & & $(72,7 \%)$ & $(78,0 \%)$ & & \\
\hline
\end{tabular}

\section{PEMBAHASAN}

Berdasarkan diagnosis utama pada rekam medis RSUP. M. Djamil Padang periode 2011-2013, pada penelitian ini ditemukan sebanyak 97 pasien SKA pada usia $\leq 45$ tahun atau sekitar 7,64 \% dari 1269 orang pasien SKA, namun hanya 66 pasien yang memenuhi kriteria inklusi dikarenakan beberapa data pasien tidak memiliki informasi yang lengkap. Temuan ini tidak jauh berbeda dengan data yang dikemukakan oleh Teixeira et al, ditemukan kejadian SKA pada usia $<46$ tahun yaitu sekitar 6,9\%. Ada perbedaan pada jenis SKA, yaitu pada penelitian ini didapatkan 42,8\% kasus APTS, 42,8 \% IMAEST dan 15,2 \% IMANEST. Sedangkan hasil yang ditemukan oleh Teixera et al yaitu sebanyak $9 \%$ APTS, $69 \%$ IMAEST, dan $1 \%$ IMANEST. ${ }^{7}$

Sebanyak 63 pasien (95,5\%) yang menjadi sampel dalam penelitian ini memiliki faktor risiko yaitu jenis kelamin laki-laki, riwayat keluarga, hipertensi, diabetes mellitus, dislipidemia dan riwayat merokok, hanya sekitar 4,5\% pasien yang sama sekali tidak memiliki faktor risiko. Rosengreen et al dalam Cardiovascular Risk Factors and Clinical Presentation in Acute Coronary Syndromes mengatakan terdapat sebanyak $12 \%$ pasien SKA yang tidak memiliki faktor risiko merokok, hipertensi, diabetes mellitus, dan dislipidemia, riwayat keluarga dan jenis kelamin tidak diteliti dalam penelitian ini. ${ }^{9}$

Pada perempuan premenoupause, estrogen diduga mempengaruhi kestabilan plak dan melindungi 
plak terhadap ruptur. ${ }^{10}$ hasil analisis bivariat dengan didapatkan nilai $\mathrm{p}=0,256$ yang artinya tidak ada hubungan antara jenis kelamin dengan kejadian SKA pada dewasa muda. Maknanya SKA dapat terjadi pada pasien laki-laki ataupun perempuan yang berusia $\leq \mathrm{cp} 45$ atau > 45 tahun. Penelitian yang dilakukan oleh Hochman et al menyatakan bahwa terdapat hubungan yang signifikan antara jenis kelamin dengan kejadian pada jenis-jenis SKA dengan nilai $\mathrm{p}=$ $0,001 .^{11}$

Pasien yang memiliki riwayat keluarga meningkatkan risiko terjadinya aterosklerosis, kecenderungan terjadinya trombosis dan respon proinflamasi oleh tingginya kadar CRP. ${ }^{12}$ Dari hasil analisis bivariat dengan Fisher's Exact Test didapatkan bahwa nilai $p=0,006$ yang artinya terdapat hubungan antara riwayat keluarga dengan kejadian SKA pada dewasa muda. Pada analisis multivariat, riwayat keluarga bukan merupakan variabel yang paling berpengaruh terhadap kejadian SKA pada dewasa muda.

Penelitian yang dilakukan oleh Leander et al juga menyatakan terdapat hubungan antara riwayat keluarga pernah menderita PJK dengan kejadian infark miokard, dengan adanya riwayat keluarga pernah menderita PJK berisiko dua kali lebih besar pada laki-laki dan 2,1 kali pada perempuan untuk terjadinya SKA. ${ }^{13}$ Begitu juga dengan penelitian yang dilakukan oleh Hawe et al, yang menyatakan ada perbedaan yang signifikan antara riwayat keluarga dengan kejadian PJK, dengan adanya riwayat keluarga berisiko 1,7 kali lebih besar dibandingkan yang tidak. ${ }^{14}$

Diabetes diperkirakan merusak faktor vasodilatasi endotel yaitu Nitric Oxide (NO). ${ }^{15}$ Hasil analisis bivariat didapatkan bahwa nilai $p=0,849$ yang artinya tidak ada hubungan antara diabetes mellitus dengan kejadian SKA pada dewasa muda.

Hal ini berbeda dengan penelitian yang dilakukan oleh Esteghamati et al pada tahun 2006 menyatakan terdapat hubungan yang signifikan antara diabetes mellitus dengan kejadian SKA (nilai $\mathrm{p}<$ 0,001). ${ }^{16}$ Penelitian lain oleh Rosengren et al pada tahun 2005 juga menemukan terdapat hubungan antara diabetes mellitus dengan kejadian SKA (nilai $p$ $<0,0001)^{9}$
Pada hipertensi terjadi peningkatan tekanan pada arteri yang menyebabkan kekakuan pada dinding pembuluh, menyebabkan infark miokard bersamaan dengan proses rupturnya plak dan faktor risiko yang lainnya (Haider et al, 2003). ${ }^{17}$ Hasil analisis bivariat didapatkan bahwa nilai $p=0,002$ yang artinya terdapat hubungan antara hipertensi dengan kejadian SKA pada dewasa muda. Berdasarkan analisis multivariat didapatkan bahwa hipertensi merupakan faktor risiko kejadian SKA pada dewasa muda bahwa dengan adanya hipertensi berisiko 0,301 kali lebih besar untuk terjadinya SKA dibandingkan dengan yang tidak menderita hipertensi.

Penelitian oleh Rosengren et al, menyatakan terdapat hubungan yang signifikan antara hipertensi dengan kejadian SKA ( $p<0,0001)$ dan pada analisis multivariat juga didapatkan dengan adanya hipertensi risiko terjadinya SKA adalah sekitar 0,75 kali dibanding yang tidak menderita hipertensi. ${ }^{9}$ Penelitian lain yang dilakukan oleh Esteghamati et al juga menyatakan bahwa terdapat hubungan antara hipertensi dan kejadian SKA dengan nilai $p<0,05 .{ }^{16}$

Peningkatan kadar LDL teroksidasi berperan penting dalam proses inflamasi pada plak aterosklerosis. ${ }^{18}$ Analisis bivariat didapatkan bahwa nilai $p=0,141$ yang artinya tidak ada hubungan antara dislipidemia dengan kejadian SKA pada dewasa muda. Pada analisis multivariat, dislipidemia bukan merupakan variabel yang paling berpengaruh terhadap kejadian SKA pada dewasa muda.

Penelitian yang dilakukan oleh Ehara et al menunjukan terdapat hubungan yang signifikan antara tingginya kadar LDL teroksidasi dengan kejadian SKA dengan nilai $p<0,00005$ pada APTS dan $p<0,0001$ pada infark miokard. ${ }^{18}$ Perbedaan hasil penelitian ini disebabkan karena adanya perbedaan pada karakteristik sampel dan pada penelitian Ehara et al, yang dilihat hanya hubungan tingginya kadar LDL. Selain itu penelitian yang dilakukan oleh Rosengren et al di Eropa juga menunjukan adanya hubungan yang signifikan antara hiperlipidemia dengan kejadian SKA dengan nilai $p<0,0001 .^{9}$ Penelitian oleh Supriyono juga menunjukan hasil yang berbeda yaitu terdapatnya hubungan yang signifikan antara dislipidemia dengan kejadian PJK pada usia $<45$ tahun dengan nilai $p=$ 0,029 dan pada analisis multivariat ditemukan bahwa 
dengan adanya dislipidemia berisiko 2,8 kali lebih besar untuk terjadinya PJK dibandingkan dengan yang tidak menderita dislipidemia. ${ }^{19}$

Merokok meningkatkan oksidasi LDL dan menganggu fungsi vasodilatasi endotelial (Ridker et al, 2001). ${ }^{20}$ Hasil analisis bivariat dengan uji kai-kuadrat didapatkan bahwa nilai $\mathrm{p}=0,288$ yang artinya tidak ada hubungan antara riwayat merokok dengan kejadian SKA pada dewasa muda.

Penelitian yang dilakukan oleh Esteghamati et al menyatakan terdapat hubungan yang signifikan antara riwayat merokok dengan kejadian SKA terutama pada infark miokard dengan nilai $p<0,005$. $^{16}$ Penelitian yang dilakukan oleh Rosengren et al juga menunjukan terdapat hubungan yang signifikan antara riwayat merokok dengan kejadian SKA dengan nilai $p$ $<0,006$, namun pada penelitian Rosengren et al ada beberapa data yang hilang atau tidak lengkap tentang riwayat merokok sehingga yang dihitung hanya current smoker. ${ }^{9}$ Penelitian lain yang dilakukan oleh Pitsavos et al menyatakan bahwa perokok memiliki risiko 2,83 kali lebih besar terkena PJK dan risiko terjadinya SKA pada perokok pasif yang sering terekspos oleh asap rokok adalah $47 \%$ lebih besar dibanding yang tidak pernah terekspos sama sekali. ${ }^{21}$

\section{KESIMPULAN}

Terdapat hubungan hipertensi dan riwayat keluarga terhadap kejadian sindroma koroner SKA pada dewasa muda di RSUP M. Djamil Padang periode 2011-2013.

Tidak terdapat hubungan jenis kelamin, riwayat merokok, dislipidemia, dan diabetes mellitus dengan kejadian sindroma koroner akut pada pasien dewasa muda di RSUP M. Djamil periode 2011-2013.

\section{DAFTAR PUSTAKA}

1. Allison TG. Coronary heart disease epidemiology dalam Mayo Clinic Cardiology. Edisi ke-3. Mayo Clinic Scientific Press. Minnesota.2007.

2. Go AS, Mozaffarian D, Roger VL, Benjamin EJ, Berry JD, Blaha MJ, et al. Heart disease and stroke statistics 2014 update: a report from the American heart assosiation. Circulation. 2014;129:e28-e292.
3. Riset Kesehatan Dasar. 2013. (diunduh 6 Juni 2014). Tersedia dari: URL: HYPERLINK http://www.depkes.go.id

4. Sangkot HS. Motalitas dan morbiditas pada pasien elektif dalam daftar tunggu operasi bedah pintas koroner di RS. Jantung dan Pembuluh Darah Harapan Kita tahun 2010 (tesis). Universitas Indonesia; 2010.

5. Hamm CW, Bassan JP, Agewall S, Bax J, BoersmaE, Bueno $\mathrm{H}$, et al. ESC guidelines for the management of acute coronary syndromes in patients presenting without persistent ST-segment elevation. European Heart Journal. 2011;32:2999_ 3054.

6. Kumar A. Acute coronary syndromes: diagnosis and management, Part I. Mayo Clinic Proceedings. 2009;84(10):917-938.

7. Teixeira M, Isabel SA, Mendes JS, Martins L. Acute coronary syndromes in young adults. Rev Port Cardiol. 2010;29:June 10.

8. Kolansky DM. Acute coronary syndromes: morbidity, mortality, and pharmacoeconomic burden. American Journal of Managed Care.2009. Published online, March 23, 2009.

9. Rosengren A, Walentin L, Simoons M, Gitt AK, Behar S, et al. Cardiovascular risk factors and clinical presentation in acute coronary syndromes. Heart. 2005;91:1141-7.

10. Burke AP, Farb A, Malcom G, Virmani R. Effect of menopause on plaque morphologic characteristics in coronary atherosclerosis. American Heart Journal. 2001;141:58-62.

11. Hochman JS, Tamis JE, Thompson TD, Weaver WD, White HD, et al. Sex, clinical presentation, and outcome in patients with acute coronary syndromes. NEJM. 1999;341:226-32.

12. Nasir K, Michos ED, Rumberger JA, Braunstein JB, Post WS, et al. Coronary artery calcification and family history of premature coronary heart disease. Circulation. 2004;110:2150-6.

13. Leander K, Hallqvist J, Reuterwall C, Ahlbom A, Faire UD. Family history of coronary heart disease, a string risk factor for myocardial infarction interacting with other cardiovascular risk factors: 
result from the Stockholm Heart Epidemiology

Program (SHEEP). Epidemiology.2001;12(2):215-

21.

14. Hawe E, Talmud PJ, Miller GJ, Humphries E. Family history is a coronary heart disease risk factor in the second northwick park heart study. Annals of Human Genetics. 2003;67:97-106.

15. Beckman JA, Creager MA, and Libby P. Diabetes and Atherosclerosis. JAMA. 2002;287(19):2570-81.

16. Esteghamati A, Abbasi $M$, Nakhjavani $M$, Yousefizadeh A, Basa AP, Afshar H. Prevalence of diabetes and other cardiovascular risk factors in an Iranian population with acute coronary syndrome. Cardiovascular Diabetology. 2006;5:15.

17. Haider AW, Larson MG, Franklin SS, Levy D. Systolic blood pressure, diastolic blood pressure, and pulse pressure as predictors of risk for congestive heart failure in the Framingham Heart Study. Ann Intern Med. 2003;38:10.
18. Ehara S, Ueda M, Naruko T, Haze K, Itoh A, et al. Elevated levels of oxidized low density lipoprotein show a positive relationship with the severity of acute coronary syndromes. Circulation. 2001;103:1955-60.

19. Supriyono M. Faktor-faktor risiko yang berpengaruh terhadap kejadian penyakit jantung koroner pada kelompok usia $\leq 45$ tahun. Universitas Diponegoro; 2008.

20. Ridker PM, Ganest J, Libby P. Risk factors for atherosclerotic disease in Braunwald E. Heart Disease, a text book of cardiovascular medicine. Edisi ke-6. Philadelphia: WB Saunders co; 2001. hlm.1010-31.

21. Pitsavos C, Panagiotakos DB, Chrysohoou C, Skoumas J, Tzioumis K, et al. Association between exposure to environmental tobacco smoke and the development of acute coronary syndromes: the cardio 2000 case-control study. Tobacco Control. 2002:220-5. 